\title{
Preheating Cold Supply Air to Mechanical Balanced Ventilation using Wastewater or Passive Geothermal Energy
}

\author{
Behrouz Nourozi ${ }^{1}$, Qian Wang ${ }^{1,2}$, Adnan Ploskić ${ }^{1,3}$ \\ ${ }^{1}$ Division of Fluid and Climate Technology, School of Architecture and Built Environment \\ KTH Royal Institute of Technology, Stockholm, Sweden \\ ${ }^{2}$ Uponor AB, Västerås, Sweden \\ ${ }^{3}$ Bravida Holding AB, Hägersten, Sweden
}

\begin{abstract}
This study investigated the thermal potential of two renewable heat sources, residential wastewater and geothermal energy, for preheating the incoming air to the air-handling unit (AHU) in a multi-family building. The main purpose of preheating the inlet air was to avoid the frost formation inside AHU due to low outdoor temperatures during winter. Wastewater extraction flowrate and temperature, as two design parameters, were studied in detail by employing two types of wastewater storage tanks.

The suggested outdoor air preheating systems equally reduced the defrosting period to $26 \%$ compared to the mechanical ventilation with heat recovery system (MVHR) without air preheating. The system that utilized a temperature stratified wastewater storage tank provided a higher ratio of heat output to electricity input. The other outdoor air preheating system, which was equipped with an unstratified wastewater storage tank, provided a lower ratio of heat output to pumping power. However, this ratio was not disturbed by variations in outdoor air temperature.
\end{abstract}

\section{Introduction}

Following the 2010 directive of the European Parliament on the energy performance of buildings ("Directive 2010/31/EU of the European Parliament" 2010), the Swedish government has foreseen $50 \%$ reduction in total energy usage in buildings by 2050 (National programme for energy efficiency and energy-smart construction, 2006).

Heat losses through buildings' façade as well as through ventilated air and wastewater are the major sources of thermal energy waste in buildings. Thermal losses from the used ventilation air in cold climates have efficiently been addressed by heat recovery systems. However, the moisture content in the return air from the building freezes in the MVHR heat recovery exchanger by meeting the fresh and cold outdoor air. This results in a reduced heat recovery potential, blockage of airflow, an increase in pressure loss and fan power need (Fisk et al., 1985; Rafati Nasr et al., 2014). Therefore, this study has suggested preventing frost formation in MVHR by preheating the inlet outdoor air using wastewater and geothermal energy.
The share of wasted heat by residential wastewater compared to the total building heat demand has increased in new constructions (Meggers and Leibundgut, 2011). This is mainly because of the improvements in insulating building materials and more airtight constructions, which reduced buildings heat losses by transmission/infiltration. Daily variation of wastewater temperature is within $6^{\circ} \mathrm{C}$ (Postrioti et al., 2016; Seybold and Brunk, 2013). This makes outgoing wastewater a reliable heat source for the suggested system. Recent studies investigated the potential of residential wastewater in preheating the inlet air to MVHR. Ploskić \& Wang (2018) studied the influence of outdoor air preheating during the coldest days in January in northern Sweden. It was concluded that the ventilation heating load could be decreased by $27 \%$ $40 \%$ by this system. Nourozi et al. (2019) showed that preheating the inlet air to MVHR using wastewater decreased the defrosting time by $50 \%$ in a multifamily building located in northern Sweden. However, the annual ventilation heating energy demand was not affected by outdoor air preheating.

Constant temperature of ground at lower depths compared to outdoor air temperature makes geothermal energy an interesting renewable heat source for cooling and heating in buildings. In separate measurement studies, Simanić (2016), Kempe and Jonsson (2015) and Sundin (2016) utilized the extracted heat from a borehole, without the use of a heat pump, to preheat the inlet air to multifamily buildings in Sweden. They found that the outdoor air temperature increased by $10^{\circ} \mathrm{C}-12^{\circ} \mathrm{C}$ during coldest hours and the systems were effective in reducing the defrosting need, except for the outdoor temperatures below $-15^{\circ} \mathrm{C}$.

As a general comparative study of geothermal energy and wastewater heat, this paper investigated the ratio of heat output from these sources to the required electricity input for pumps. Furthermore, the impact of the two types of wastewater storage tanks on the performance of the air preheating systems is further investigated.

\section{Methods}

The performance of the suggested systems was evaluated using dynamic simulations using the software, TRNSYS. The studied case was a multi-family house located in central Sweden where the outdoor temperature varies between $-18^{\circ} \mathrm{C}$ and +5 . The building was served with an 

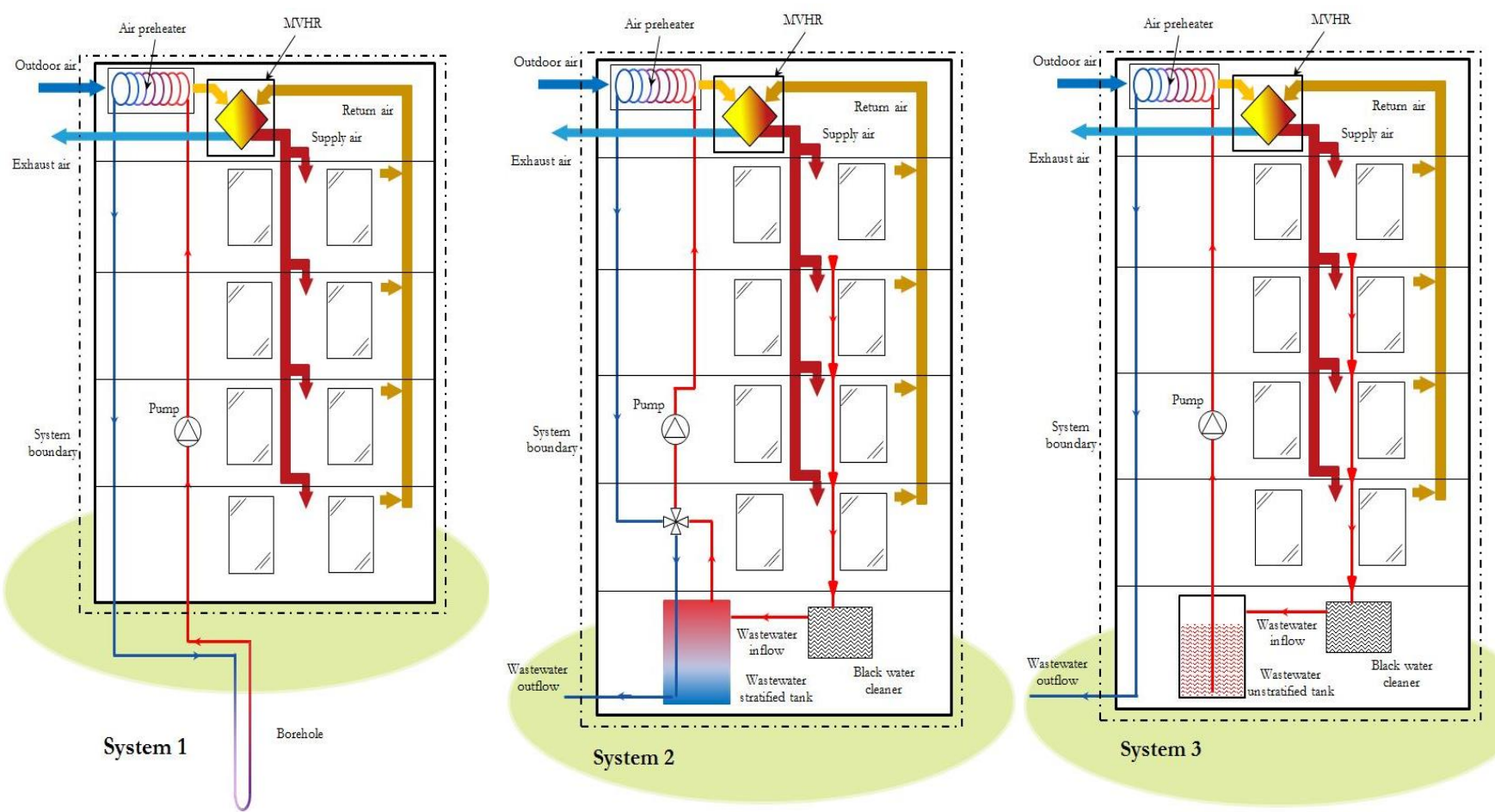

Figure 1: Studied systems, air preheater served by a) borehole (System 1), b) wastewater from the stratified tank (System 2), c) wastewater from the unstratified tank (System 3) (Nourozi et al. 2019)

MHVR system equipped with a plate air-to-air heat exchanger. The total heated floor area was $876 \mathrm{~m}^{2}$, and the ventilation airflow rate to and from the building was 4701/s. The temperature of the supplied ventilation air to the rooms was $+18^{\circ} \mathrm{C}$. The studied period was limited to four coldest months, that is from December to March (2904h) when there was a risk of frost formation in the AHU. The frosting threshold for the return air of $21^{\circ} \mathrm{C}$ and relative humidity of $30 \%$ is approximately at an outdoor air temperature of $-5^{\circ} \mathrm{C}$ (Rafati Nasr et al., 2014). Therefore, the circulation pumps in the studied air preheating systems were controlled to lift the outdoor air temperature to just above this temperature limit $\left(-5^{\circ} \mathrm{C}\right)$.

Three air-preheating systems were simulated to evaluate their potential in reducing the frosting problem in AHU. System 1, as shown in Figure 1, exploited the heat from a passive borehole (not coupled to a heat pump) to preheat the incoming airflow to the AHU. The effective length of the borehole was $250 \mathrm{~m}$, and a solution of $29 \%$ ethanol and $71 \%$ water was circulated with a flowrate of $0.66 \mathrm{~kg} / \mathrm{s}$ to the air preheater. Systems 2 and 3 utilized the thermal potential of accumulated wastewater from the building by use of a temperature stratified and an unstratified tank, respectively. Grey water (referred to as wastewater in the paper) from the disposed wastewater is separated and stored in the studied storage tanks. The hourly variations of wastewater temperature and flowrate were used as inputs for simulations. The wastewater temperature varied between $19^{\circ} \mathrm{C}-25^{\circ} \mathrm{C}$ and its daily volume was $4 \mathrm{~m}^{3}$ (during 24 hours). The minimum cooled return wastewater temperature was $4^{\circ} \mathrm{C}$. This temperature was controlled by bypassing the cold outdoor air from the air preheater to the MVHR. This would ascertain that wastewater did not freeze in the air preheater when the outdoor air temperature was low.

For System 2, the discarded wastewater from the building entered to and was extracted from the top of the stratified storage tank where the highest temperature was available. The wastewater extraction flowrate from the tank to the air preheater was $0.2 \mathrm{~kg} / \mathrm{s}$. The cooled wastewater was returned to the bottom section to ascertain the maximum wastewater volume and maintain the temperature stratification in the tank. For System 3, an insulated unstratified tank assured the highest temperature of wastewater since the returned cooled wastewater from the air preheater was released directly to the sewage system. The circulation pump, in this case, provided $0.065 \mathrm{~kg} / \mathrm{s}$ of wastewater flow rate to the air preheater.

\section{Results and Discussion}

The extracted heat from the mentioned heat sources using the studied systems are compared, and the results are provided in this section.

Figure 2 illustrates the brine and wastewater supply temperature to the air preheater. For System 1, the extracted brine temperature varied between $3^{\circ} \mathrm{C}-8^{\circ} \mathrm{C}$ in the studied period. Although the temperature variation range is small, it was affected by the cold outdoor temperature.

The top and bottom section temperatures of the stratified tank are also shown in Figure 2. There are abrupt fluctuations in temperature due to cold outdoor air (high load) and continuous extraction of wastewater in the stratified tank. Temperature stratification was limited 

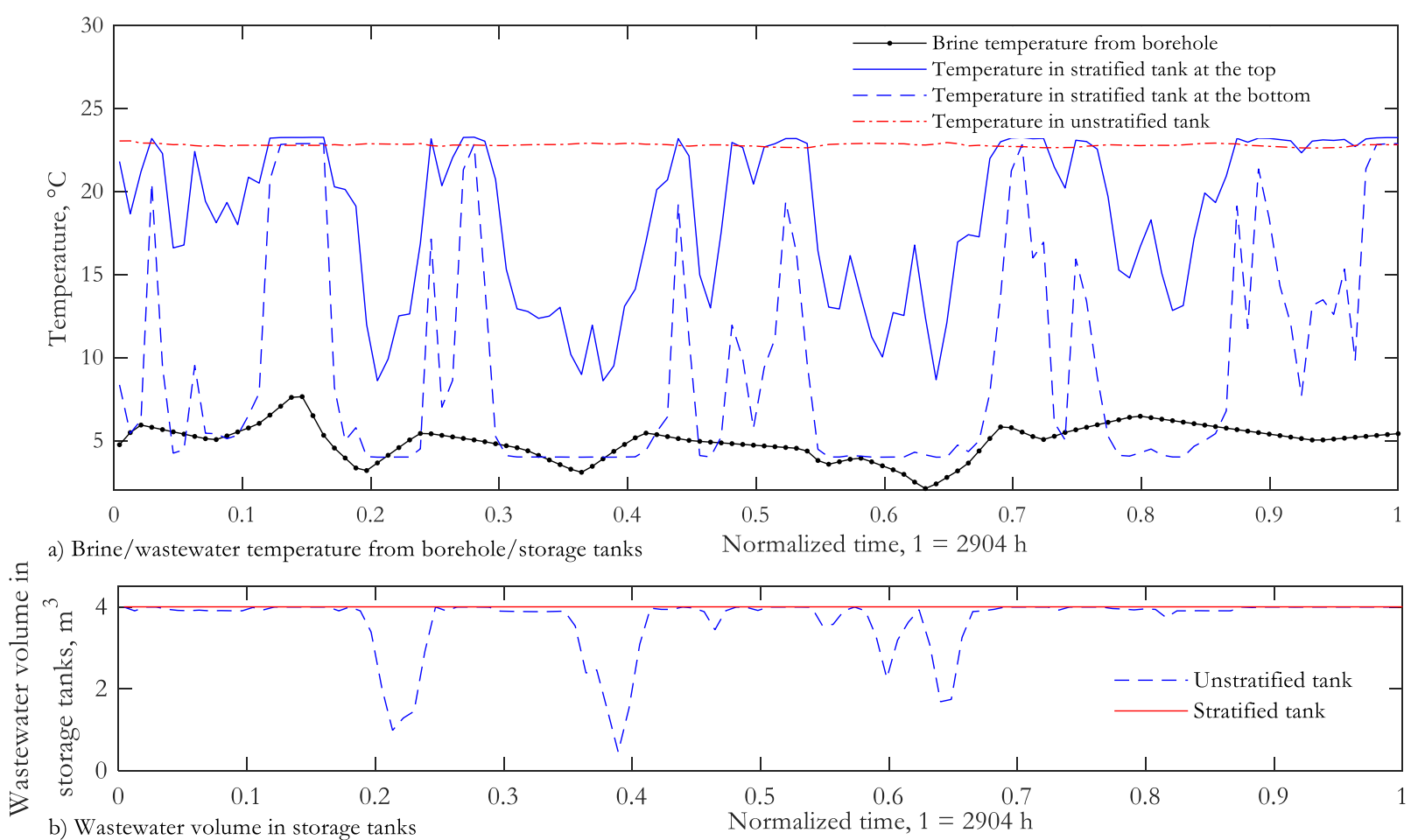

Figure 2: Brine/wastewater temperatures and volume from borehole/storage tanks

during both very cold and warm periods; however, wastewater extraction temperature dropped during the coldest hours when the returned cooled wastewater was mixed in the tank. During highest heat loads (coldest outdoor temperatures), the maximum wastewater temperature decreased to $8.6^{\circ} \mathrm{C}$. Although the wastewater reserve volume in the tank was maintained at maximum, the plunge in extraction wastewater temperature affected the transmitted heat rate to the outdoor air.

For the unstratified tank used in System 3, wastewater temperature remained undisturbed during the extraction periods. The average temperature was $23^{\circ} \mathrm{C}$, which was approximately equal to the daily mean temperature of the outgoing wastewater from the building. The reserved wastewater in the unstratified tank as shown in Figure $2 b$ was mostly maintained at the maximum level $\left(4 \mathrm{~m}^{3}\right)$ except for long periods of cold outdoor temperatures. The set value for the minimum wastewater volume in the tank was $100 \mathrm{~L}(=2.5 \%$ of the maximum volume). Therefore, System 3 had wastewater shortage only at one point within the evaluated period (at $1120 \mathrm{~h}$ ). This corresponded to the outdoor temperature equal to $-18^{\circ} \mathrm{C}$ with the duration of 4 hours.

Figure 3 illustrates the ratio of transmitted heat output to the required pumping power need (electricity input). According to the previous findings by Nourozi et al. (2019), all three studied systems equally reduced the defrosting time to $26 \%$; from initially $34 \%$ to $9 \%$ of the evaluated time (2904 h). However, System 1, as shown in Figure 3, had the lowest heat output-to-electricity input ratio, which is mainly due to the high required pumping power. System 1 had higher brine flowrate compared to wastewater flowrate in Systems 2 and 3. However, lower temperature of brine compared to wastewater decreased the transferred heat rate to the incoming airflow in this system.

System 3, as compared to System 1, showed higher potential in providing the recovered heat to the inlet air to MVHR; even though, the limitation of the stored wastewater volume in the tank hindered this system to recover more heat from the source. System 3 was designed based on the discarded wastewater flowrate from the building and the lowest outdoor temperature in the studied region. Therefore, the heat source (wastewater) shortage in the storage tank only occurred once during the studied period, which corresponded to the lowest outdoor temperature.

System 2 had the highest heat output-to-electricity ratio. Availability of wastewater reserve in this system made heat recovery from wastewater possible during periods of very low outdoor temperatures (peak loads). Nevertheless, circulation of highly cooled wastewater $\left(4^{\circ} \mathrm{C}\right)$ from the air preheater to the storage tank limited the temperature stratification in the tank, as shown in Figure $2 \mathrm{a}$. Therefore, the required pumping power was constant during most of the evaluated period but the recovered heat rate for the wastewater significantly decreased due to the reduced extraction temperature at the top of the tank. This has been reflected by abrupt fluctuations of the heat output-to-electricity input ratio in Figure 3. 


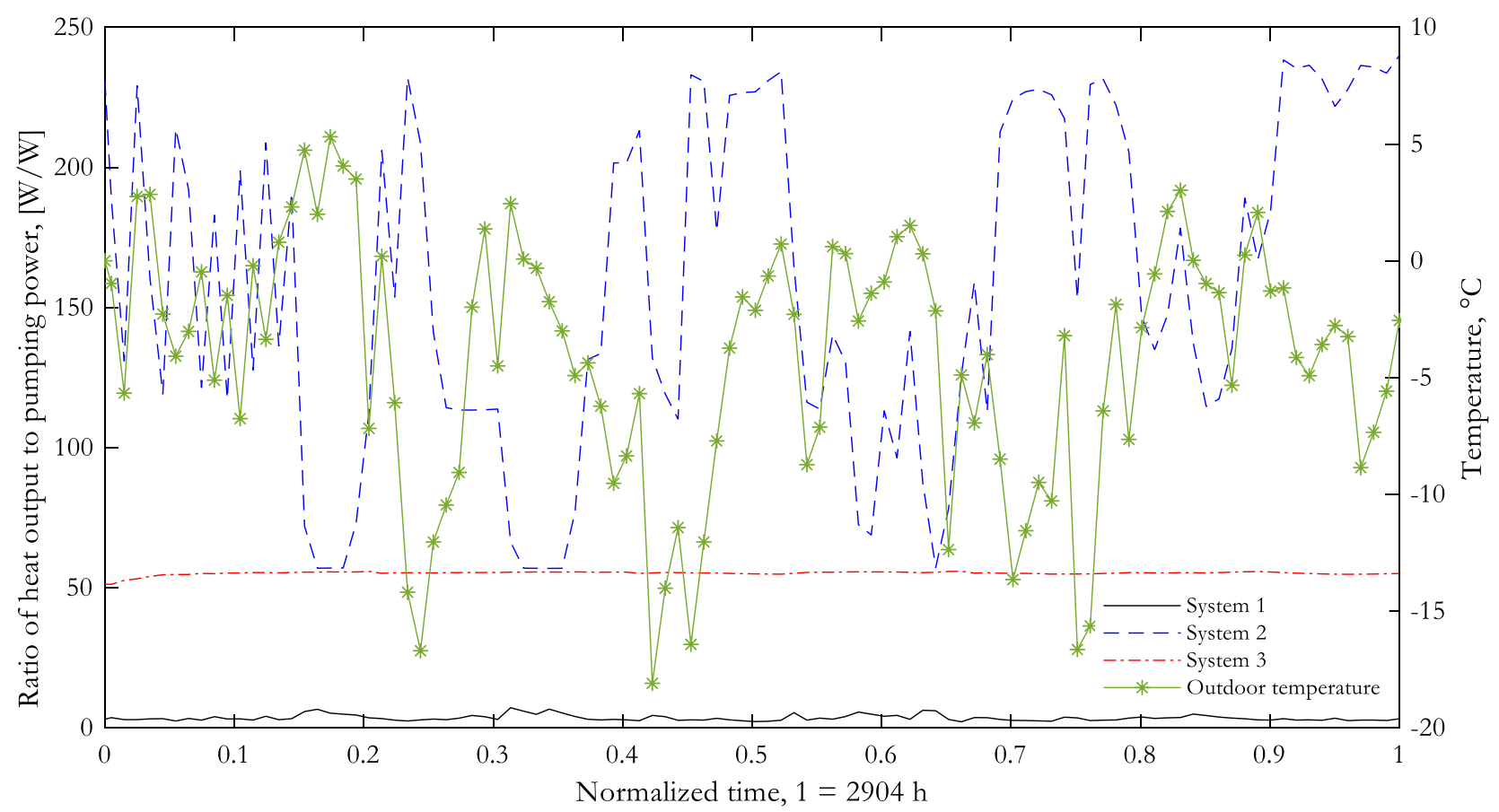

Figure 3: Transmitted heat rate to required pumping power per heated floor area

\section{Conclusion}

This study evaluated the thermal potential of two renewable heat sources to improve the performance of a building's ventilation system. The recovered heat from a borehole and residential wastewater was used to preheat the inlet air to MVHR. Preheating the outdoor air reduced the possibility of frosting in AHU during cold season.

Simulation results for three studied air-preheating systems showed that:

- System 1 (see Figure 1), had the lowest heat output-to-electricity input ratio. This was mainly due to high pressure losses of the borehole heat exchanger (collector), and consequently a highpumping power requirement.

- System 2 had the highest heat output-toelectricity input ratio, especially during the coldest hours (peak load). However, this ratio was associated with abrupt fluctuations in transmitted heat output, which in turn, was a result of a high load (low outdoor temperatures).

- The cooled return wastewater from the air preheater decreased temperature stratification in the stratified tank. Therefore, lower supply wastewater temperature reduced the transferred heat rate to the outdoor air.

- System 3 provided a constant heat output-toelectricity input ratio during the entire studied period. Utilization of an unstratified wastewater storage tank ensured the highest supply wastewater temperature to the outdoor air. This resulted in a more stable response to the outdoor air temperature variations.
- Limitations in wastewater volume in the unstratified wastewater storage tank restricted the heat recovery potential and the amount of transferred heat to the inlet air to AHU (in case of System 3).

\section{Acknowledgement}

This work is financially supported by SBUF (Development Fund of Swedish Construction Industry) and the Swedish Energy Agency. Contributions from SBUF, the Swedish Energy Agency, Bravida Holding AB and Uponor $\mathrm{AB}$, Valvet Förvaltning $\mathrm{AB}, \mathrm{AB}$ Stockholmshem, WSP Sverige AB and Telge Bostäder in providing valuable information and practical support are acknowledged. The authors would also gratefully appreciate the support from Professor Sture Holmberg from the Division of Fluid and Climate Technology at the KTH Royal Institute of Technology.

\section{References}

Directive 2010/31/EU of the European Parliament and of the Council of 19 May 2010 on the energy performance of buildings. (2010). Retrieved from http://eur-lex.europa.eu/legal-

content/EN/TXT/PDF/?uri=CELEX:32010L0031 $\&$ from $=$ en

Fisk, W. J., Chant, R. E., Archer, K. M., Hekmat, D., Offermann, F. J., \& Pedersen, B. S. (1985). Performance of residential air-to-air heat exchangers during operation with freezing and periodic defrosts (Vol. 91, pp. 159-172). ASHRAE. 
Retrieved

from https://www.scopus.com/record/display.uri?eid=2s2.0-0022185013\&origin=resultslist

Kempe, P., \& Jonsson, R. (2015). BeBo-evaluation, Newly built multi-family house with preheated air using heat from boreholes - HSB-FTX geo-energy without heat pump (BeBo-utvärdering, Nybyggt flerbostadshus med förvärmning med borrhålsvatten - HSB-FTX geoenergi utan värmepump), Technical. Retrieved from http://www.bebostad.se/library/1835/utvaerderingav-nybyggt-flerbostadshus-med-foervaermningrapport.pdf

Meggers, F., \& Leibundgut, H. (2011). The potential of wastewater heat and exergy: Decentralized hightemperature recovery with a heat pump. Energy and Buildings, 43(4), 879-886. https://doi.org/10.1016/J.ENBUILD.2010.12.008

National programme for energy efficiency and energysmart construction (2006). Ministry of Sustainable Development. https://doi.org/Government Bill 2005/06:145

Nourozi, B., Wang, Q., \& Ploskić, A. (2019). Energy and defrosting contributions of preheating cold supply air in buildings with balanced ventilation. Applied Thermal Engineering, 146. https://doi.org/10.1016/j.applthermaleng.2018.09.1 18

Nourozi, B., Wang, Q., \& Ploskić, A. (2019). Maximizing thermal performance of building ventilation using geothermal and wastewater heat. Resources, Conservation and Recycling, 143, 90-98. https://doi.org/10.1016/J.RESCONREC.2018.12.0 25

Ploskić, A., \& Wang, Q. (2018). Evaluating the potential of reducing peak heating load of a multi-family house using novel heat recovery system. Applied Thermal Engineering, 130, 1182-1190.
https://doi.org/10.1016/J.APPLTHERMALENG.2 017.11 .072

Postrioti, L., Baldinelli, G., Bianchi, F., Buitoni, G., Di Maria, F., \& Asdrubali, F. (2016). An experimental setup for the analysis of an energy recovery system from wastewater for heat pumps in civil buildings. Applied Thermal Engineering, 102, 961-971. https://doi.org/10.1016/J.APPLTHERMALENG.2 016.04.016

Rafati Nasr, M., Fauchoux, M., Besant, R. W., \& Simonson, C. J. (2014). A review of frosting in airto-air energy exchangers. Renewable and Sustainable Energy Reviews, 30, 538-554. https://doi.org/10.1016/J.RSER.2013.10.038

Seybold, C., \& Brunk, M. F. (2013). In-house waste water heat recovery. REHVA Journal, (December), 1821. Retrieved from https://www.rehva.eu/publications-andresources/rehva-journal/2013/062013/in-housewaste-water-heat-recovery.html

Simanić, B. (2016). Preheating ventilation air using heat from boreholes without use of heat pumps, case study Vivalla Örebro (Förvärmning av ventilationsluft mha borrhålsvärme utan värmepump, fallstudie Vivalla Örebro); Technical report, SBUF Development Fund of Swedish Con. Malmö. https://doi.org/12930

Sundin, M. (2016). Geothermal preheating of ventilation air: An evaluation of the ventilation efficiency of the ventilation system (Geotermisk förvärmning av ventilationsluft: En utvärdering av ventilationssystemets energieffektivitet). Uppsala University. Retrieved from http://www.divaportal.org/smash/record.jsf?pid=diva2\%3A120939 $7 \&$ dswid $=-8196$ 